اعجاز ايجاز با حذف اجزاى مختلف كلام در كلستان سعدى

عصمت خوئينى"

مهدى عيسىزاده"

קكيده

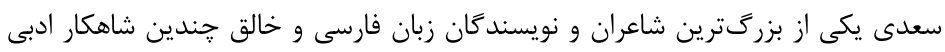

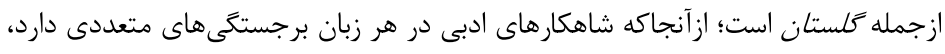

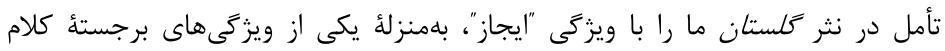

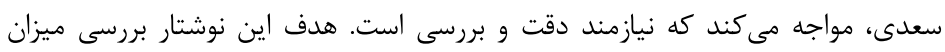

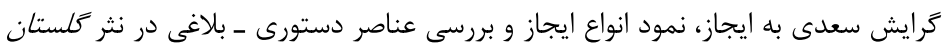

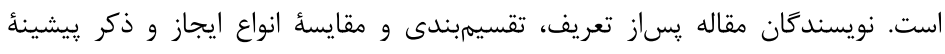

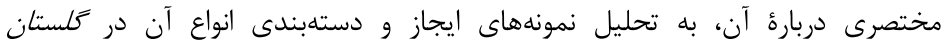

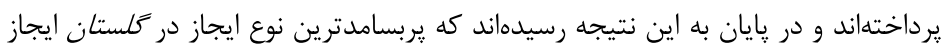

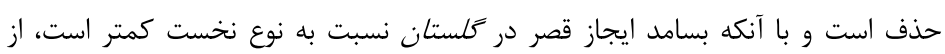

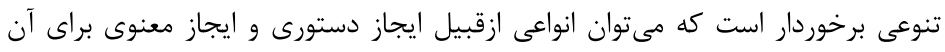
قائل شد.

$$
\text { كليدوارهها: كلستان سعدى، ايجاز حذف، ايجاز قصر، آشنايىزدايى، برجستهسازى. }
$$

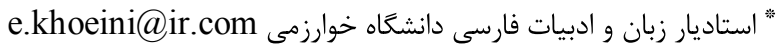

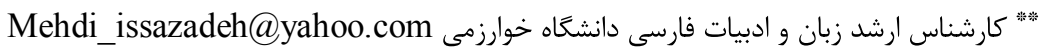

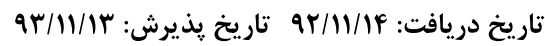

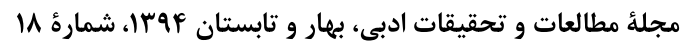


مقدمه - 20 - 20

يكى از مههترين آثار ادبيات كلاسيك فارسى كه تحقيقات بسيارى درباره آن صورت كرفته

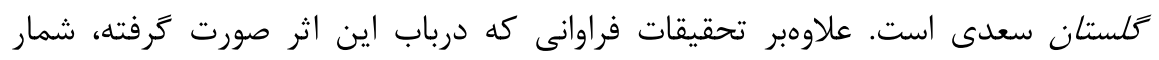

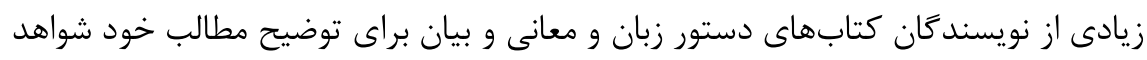

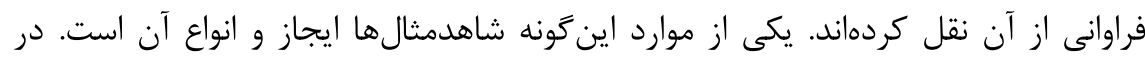

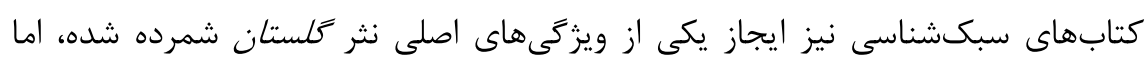

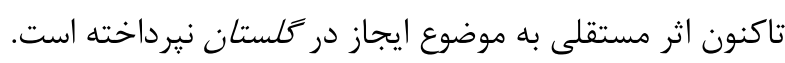

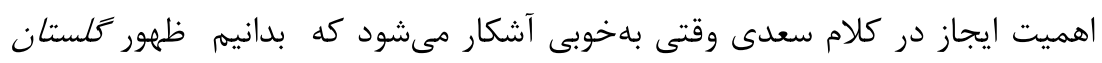

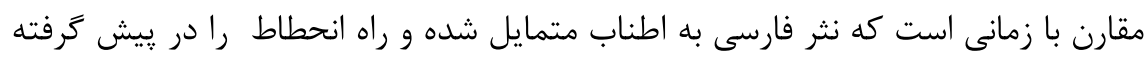

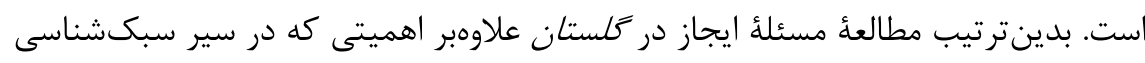

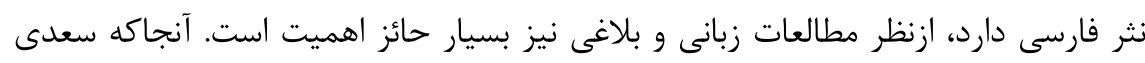

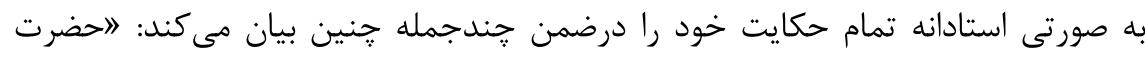

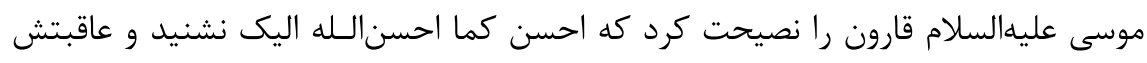

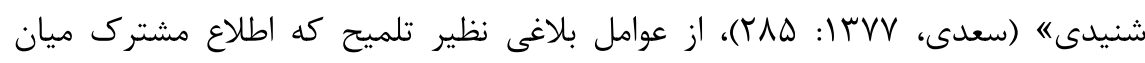

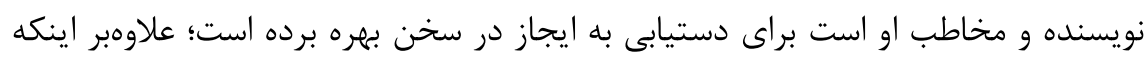

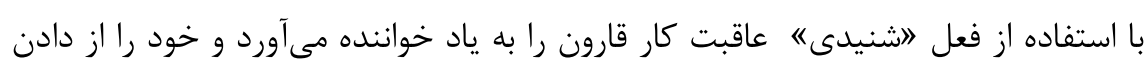
توضيح بيشتر بىنياز مى كند. اين يزوهش دريى آن است كه با رويكردى دستورى ازيكسو و ديدكاه بـاه جايخزينىهاى

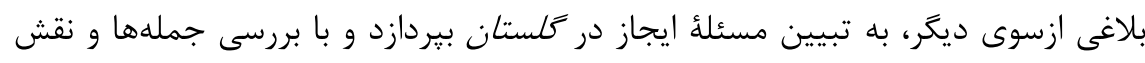

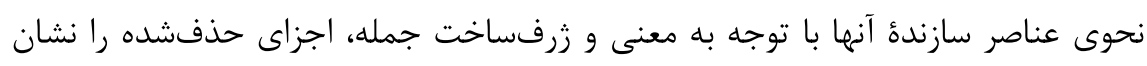

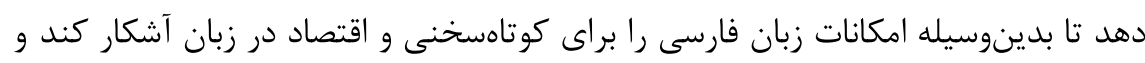
در جار جوبى قانونمند ارائه دهد.

\section{تعريف ايجاز}

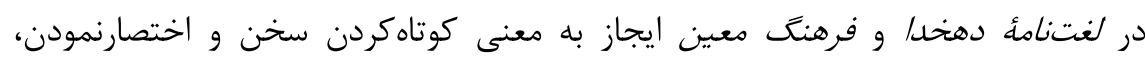

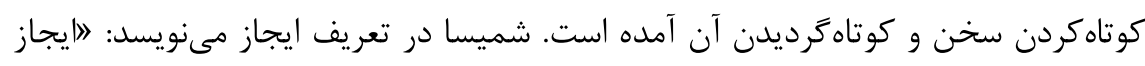

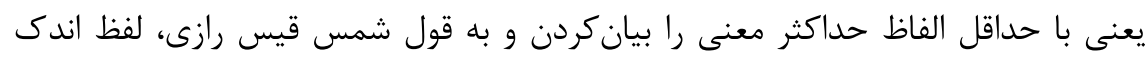

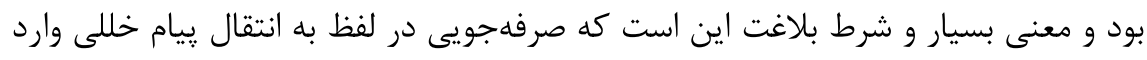

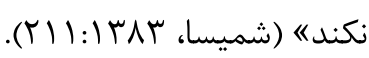

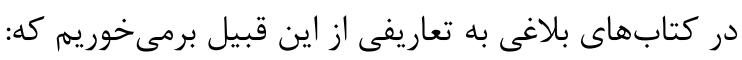




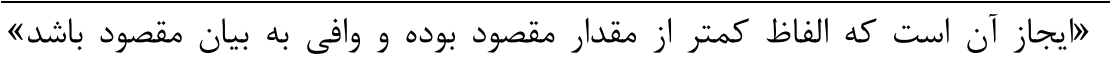

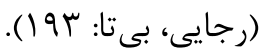

الايجاز آن است كه از معنى تعبير شود با الفاظى كه كمتر از معهود متعارف باشد با

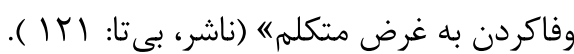

اايجاز بيان معنى است در كوتاهترين لفظ، و بهعبارت ديخر، آوردن لفظ اندك است

براى معنى بسيار كه البته بايد به رسايى سخن كمك كنده (علوىمقدم و اشرفزاده،

(V9:) r r V

$$
\text { ا. تعاريف مذكور بريائُ سه اصل بنياد نهاده شده است: }
$$

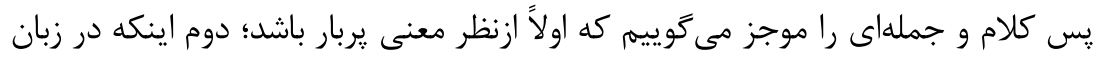

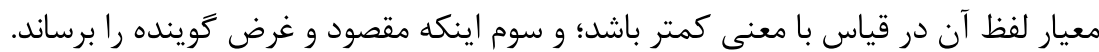
علماى علم معانى ايجاز را به دو نوع تقسيم كردهاند: ا. ايجاز قصر r. ايجاز حذف. اايجاز قصر كنجاندن معانى بسيار در الفاظ اندك است؛ بلنحوى كه حذفى هم در در عبارات صورت نخرفته باشد. بدينترتيب متكلم بايد مطلب مفصل يا تقريباً مفصلى را بدون تكلف در حداقل الفاظ ممكن بيان كند و ازاينرو ايجاز قصر را مىتوان شرح و بسط داد. در

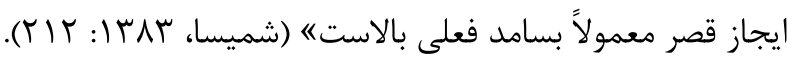
اايجاز حذف ايجازى است كه با حذف قسمتى از كلام تحقق يذيرفته باشد. در اينجا

نيز شرط بلاغت اين است كه در فهم معنى خللى وارد نشوده (همان، ساب( ).

تفاوت ايجاز قصر و حذف

الدر هر دو ايجاز الفاظ كمتر از معانى است ولى در ايجاز قصر كلام بدون حذف وازه يا

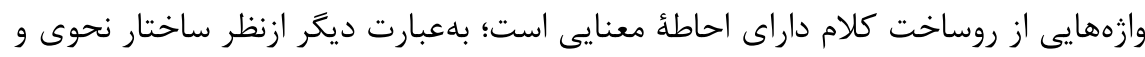

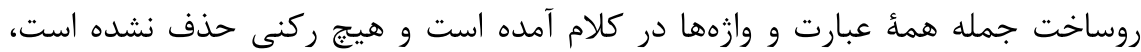
ولى در ايجاز حذف، فزونى معنى بهدليل حذف يك يا جند وازه به قرينه است و اين فزونى از زرفساخت عبارت دانسته مىشود. ايجاز قصر با همهٔ محاسنى كه دارد داراى غموض

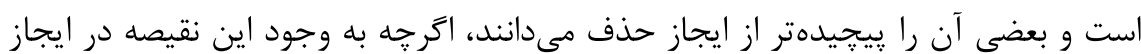
حذف نيز اعتقاد دارند. البته يِيجيدگى و ابهام ايجاز تنها از اينجهت است كه خواننده بايد به مواضعى كه حذف در آنها رواست آشنايى كامل داشته باشد و با ذهن وقّاد خود بتواند 


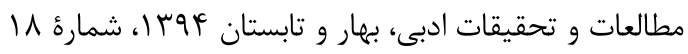

$\lambda r^{4}$

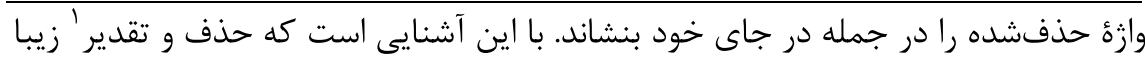

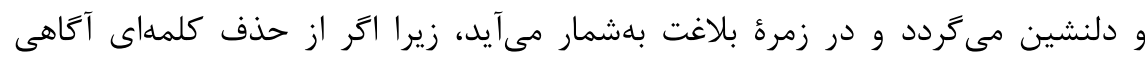

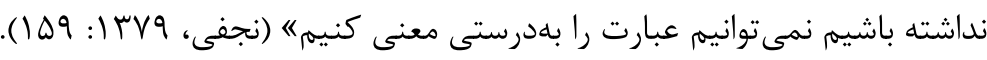

\section{بيشينة ايجاز}

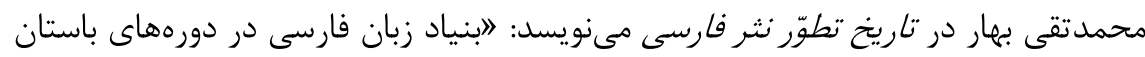

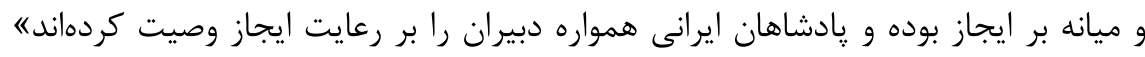

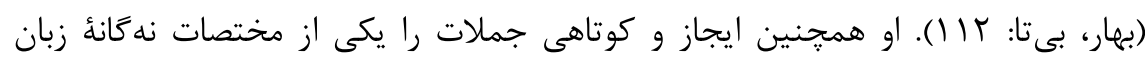

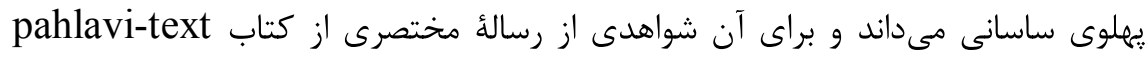

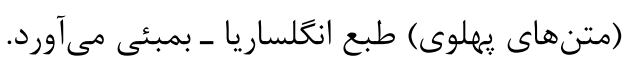

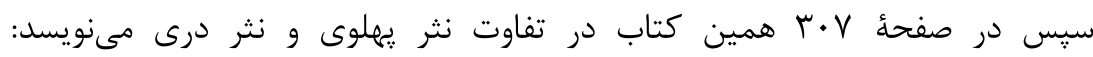

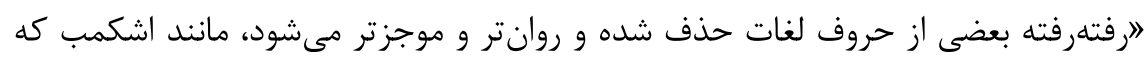

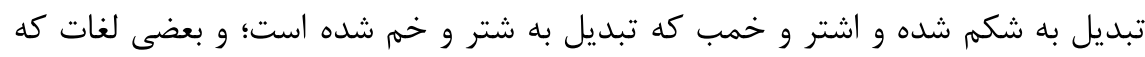

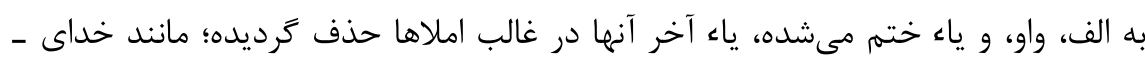

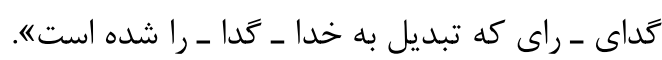

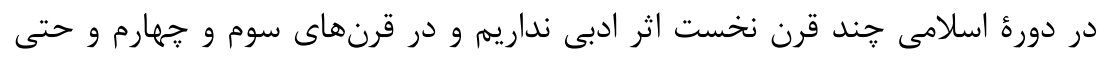

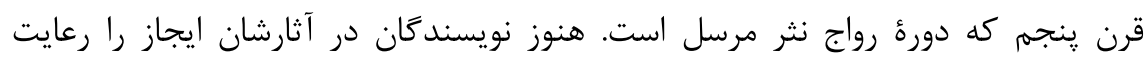

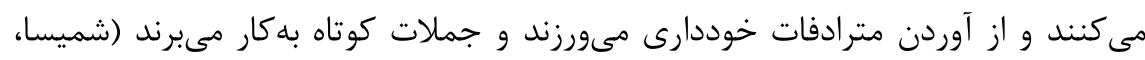

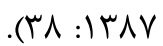

در اواخر قرن ينجمم و قرن ششم نثر فارسى به اطناب متمايل مىشود و جمله إها

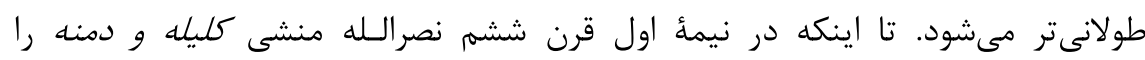

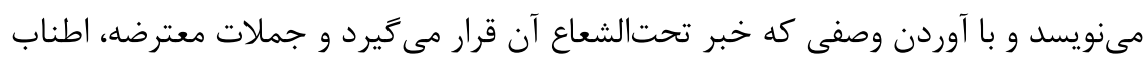

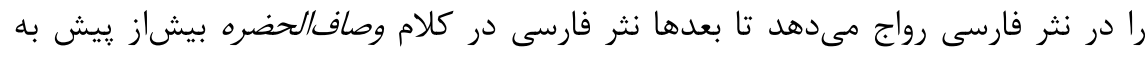

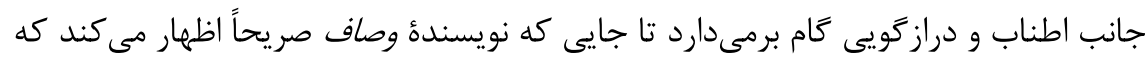

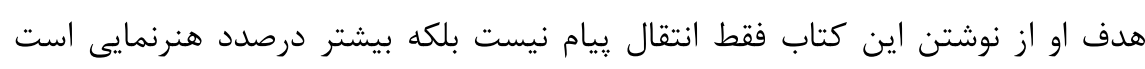

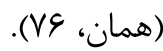

سعدى در اين دوران و جندسال يِيشاز اينكه تاريخ وصاف نوشته شود و جمله إنهاى

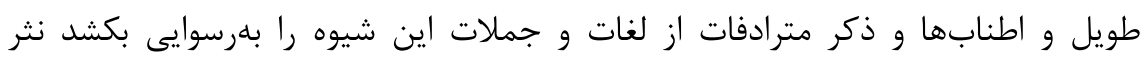

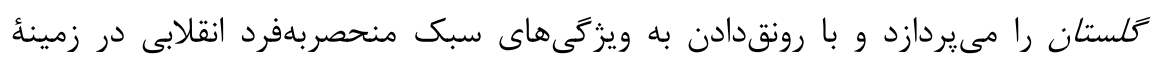
نثرنويسى ايجاد مى كند. 
يكى از مهارتهاى زبانى و هنرهاى كلامى كه بيشتر محققان در ضمن موضوعات مختلف

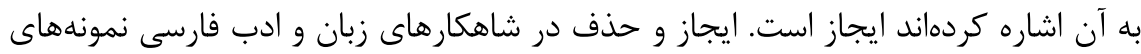

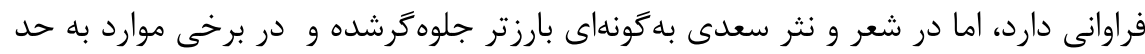

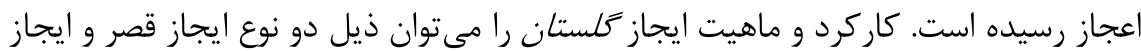
حذف هدف تجزيه و تحليل قرار داد.

ايجاز قصر در كلستان

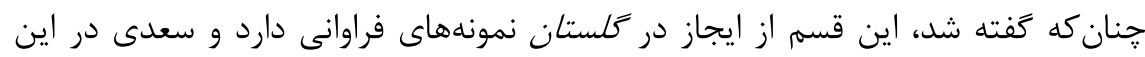

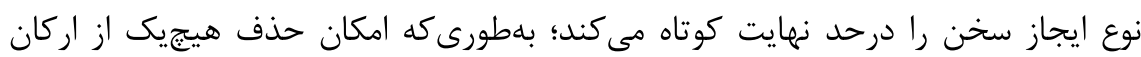

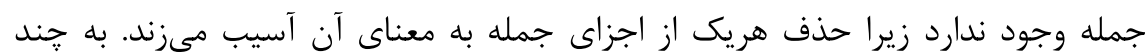
نمونه از اين نوع اشاره مى كنيم.

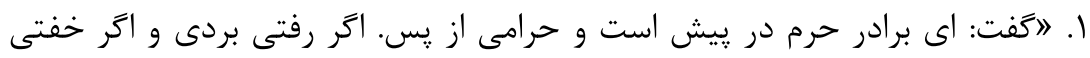

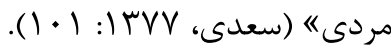
در نمونهٔ بالا، جمله دوم اسنادى است و حداقل الآل اركان اين نوع جمله در ساختمان

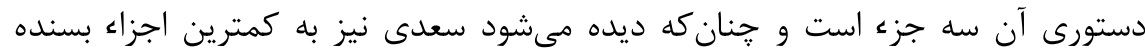
كرده است؛ بهطورى كه حذف هيجيك از آنها ممكن نيست: (حرم) + (در يیش) + (است).

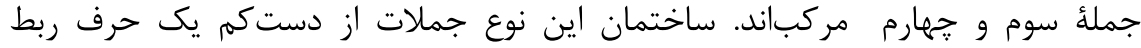

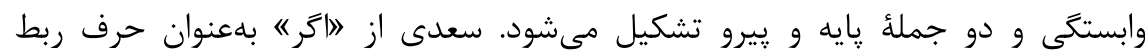
وابستهاز و از دو فعل بهمنزله كوجكترين صورت جمله (جمله پايه و وِيرو) استفاده كرده

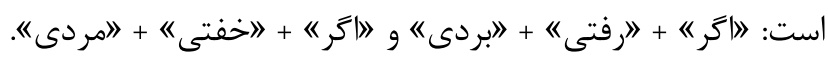

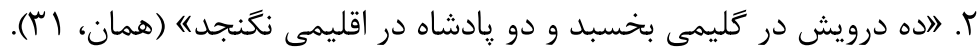

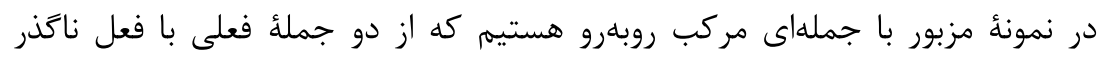
تشكيل شده است. هريك از جملهها از نهاد + متمم + فعل ساخته شدهاند؛ علاوهبر اينكه

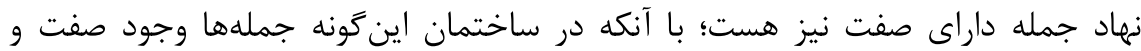

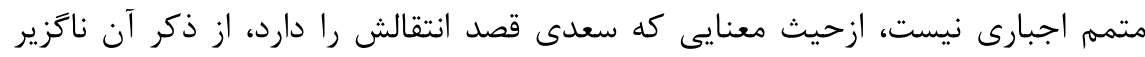

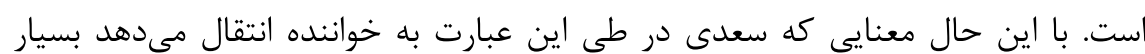

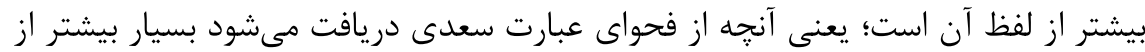




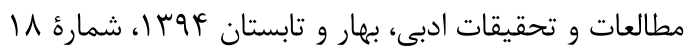

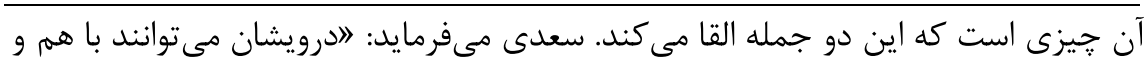

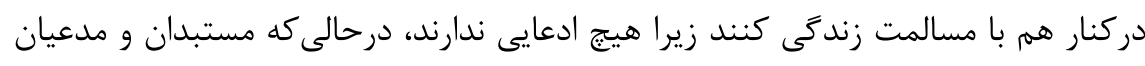

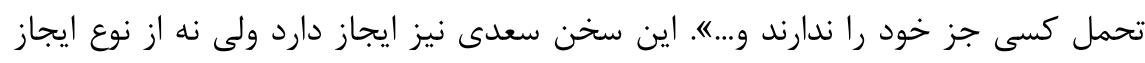

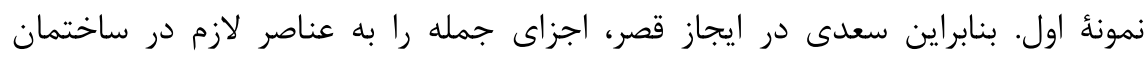

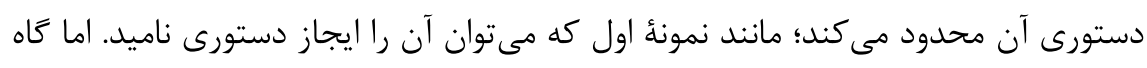

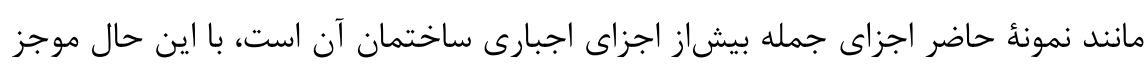

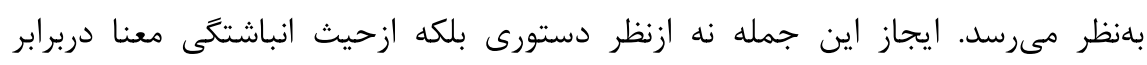

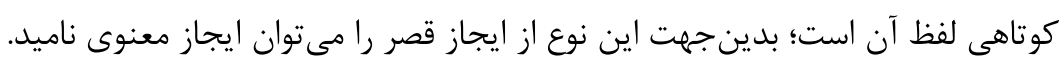

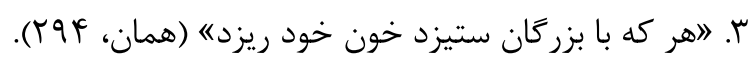

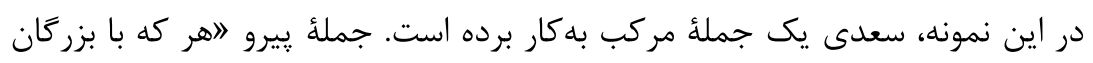

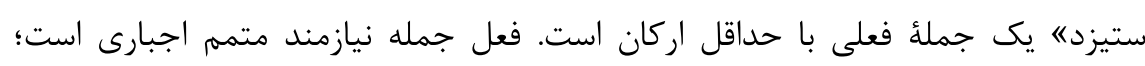

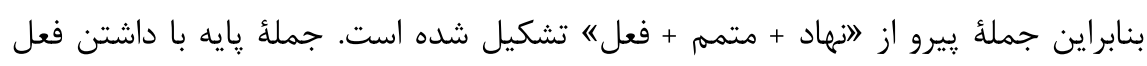

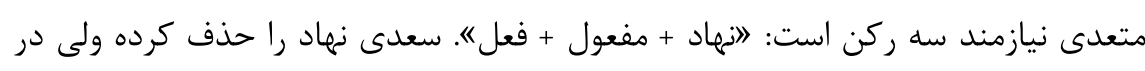

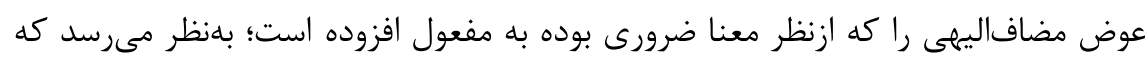

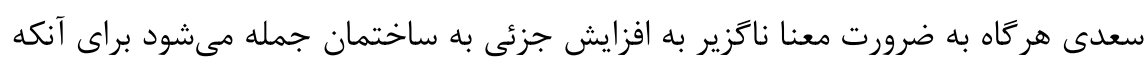

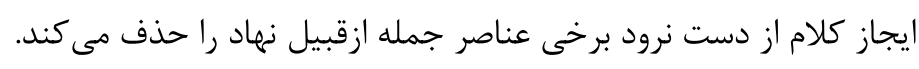

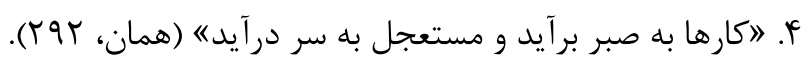

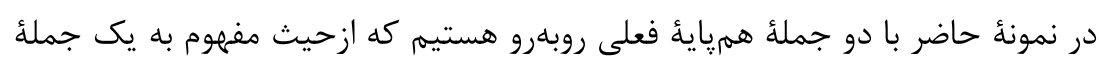

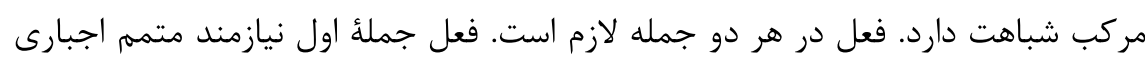

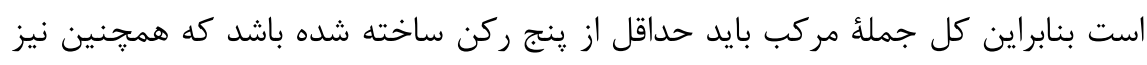

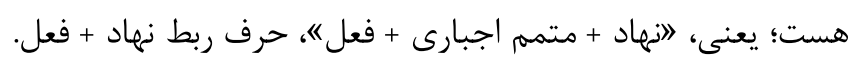

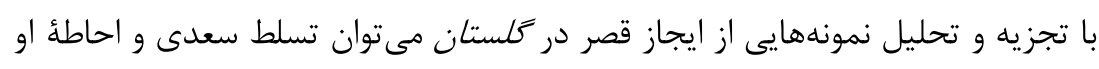

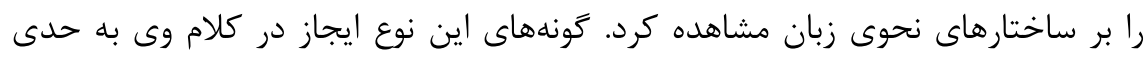

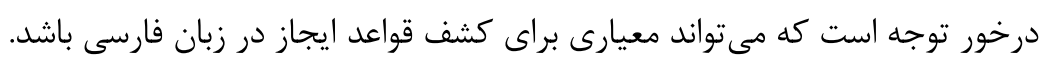

\section{تلميح و استعاره و تشبيه ابزار ايجاز}

صاحب المعجم براى ايجاز همان تعريفى را آورده كه براى تلميح آورده است. او با استناد به إسها

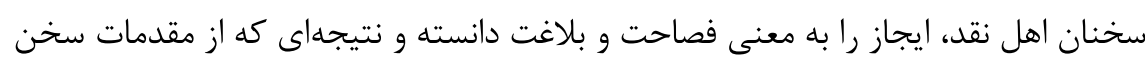

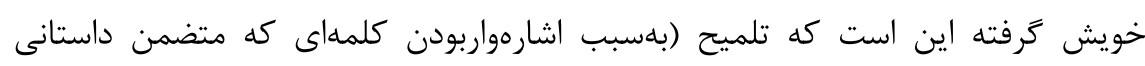

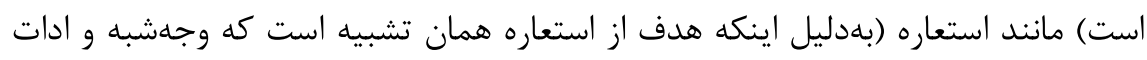


تشبيه و مشبه در آن حذف مىشود) نوعى ايجاز است. سيس استعارات و تلميحات را نيز

$$
\text { ازباب ايجاز شمرده است. }
$$

براى رعايت اختصار در اين نوشته براى هركدام از موارد تلميح و استعاره و تشبيه كه

$$
\text { موجب ايجاز در كلستان شده است دو نمونه ذكر مى كنيه. }
$$

تلميح

احضرت موسى عليهالسلام قارون را نصيحت كرد كه احسن كما احسن الـله اليك نشنيد و

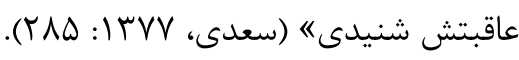

اين جملات كه خود نوعى داستان كوتاه است، براى مخاطبى آشنا با ادبيات فارسى و داستان حضرت موسى(ع) در فرهنگ اسلامى معانى بسيارى دارد. مثلاً جمله دوكلمهاى اعاقبتش شنيدى" به ماجراى فرورفتن قارون و ثروتش در زمين اشاره دارد.

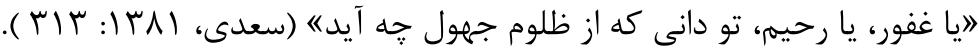
در اين جمله، وازههاى ظلوم و جهول علاوهبر اينكه صيغهُ مبالغه هستند و در فارسى به بيشاز يك وازه ترجمه مىشوند با توجه به تلميحى كه به داستان قرآنى و آئه مشهور امانت

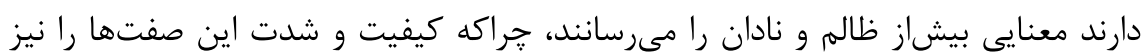
به ذهن متبادر مى كنند.

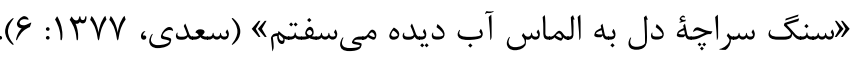

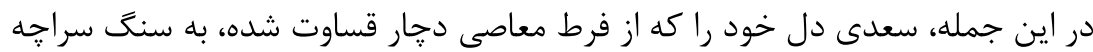
و اشك جشم خود را به الماسى كه سنگ را سوراخ و نرم مى كند تشبيه كرده است، درحالى كه اين معانى بلوسيلة دو اضافهٔ تشبيهى و با كمترين الفاظ به صورت يك جمله بيان شده است.

"جنان خواب غفلت بردهاند كه گويى مردهاند" (سعدى، IN I IV VIV). سعدى در اين جملات با تشبيه خفته به مرده، علاوهبر اينكه ازنظر غافلبودن آنها را به مرده تشبيه كرده، بقية شباهتهاى خفته و مرده را نيز درنظر دارد. ضمن اينكه جمله معنى حديث الالنوم اخ الموته را نيز براى خواننده تداعى مي كند. 


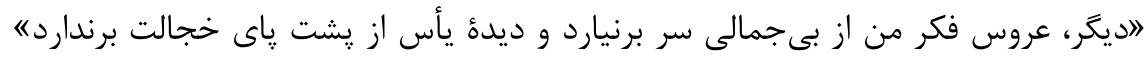

(سعدى، TrV (T) 9 9).

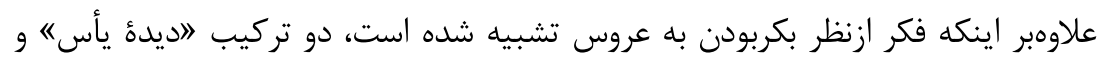

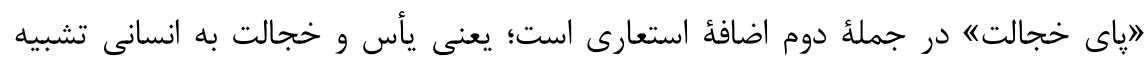

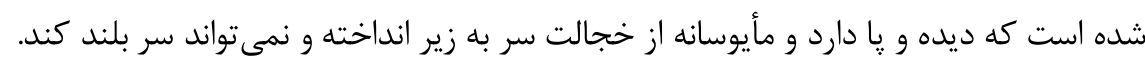

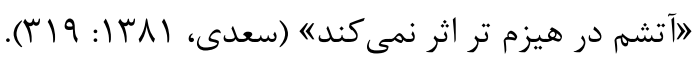

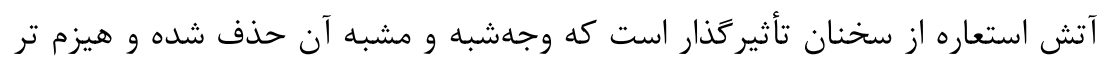

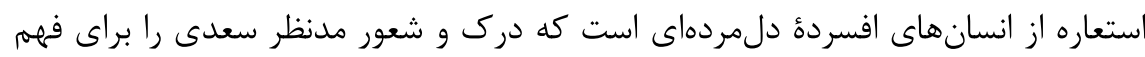

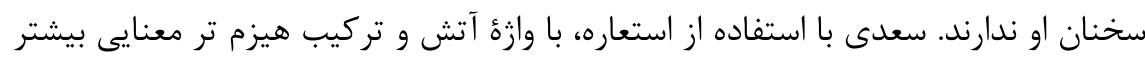
از اين الفاظ را به خواننده منتقل كرده است.

\section{ايجاز حذف در كلستان}

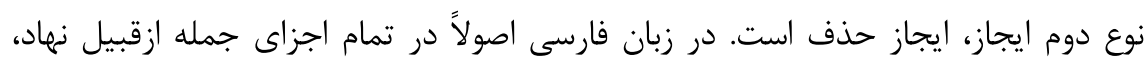

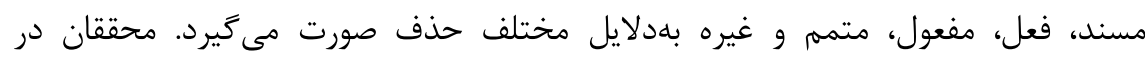

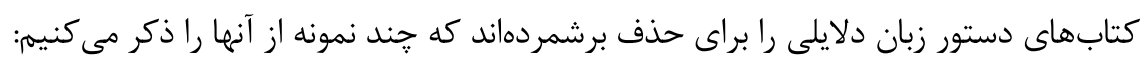

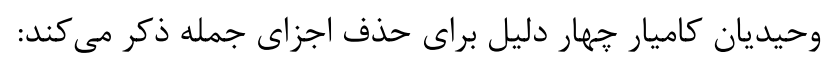

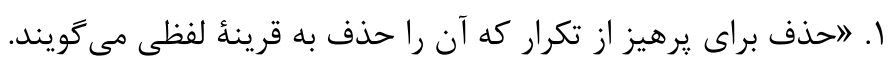

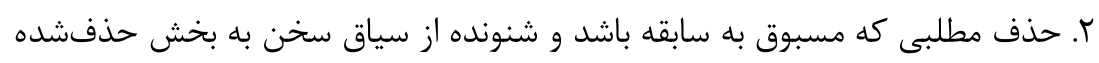

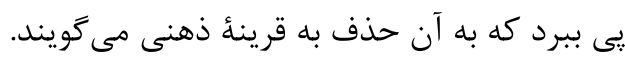

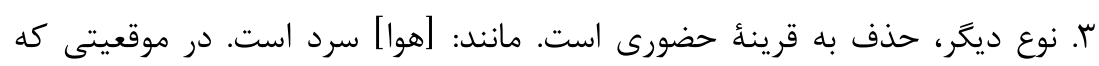

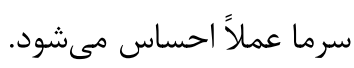

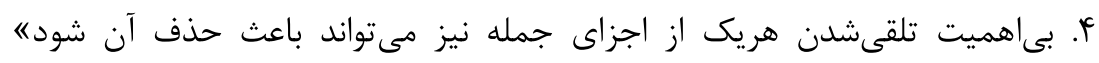

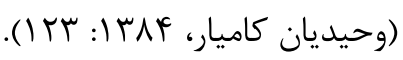

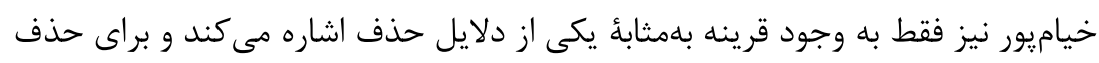

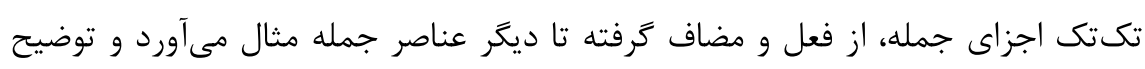

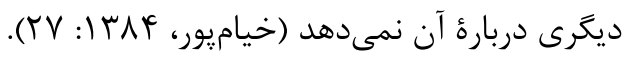

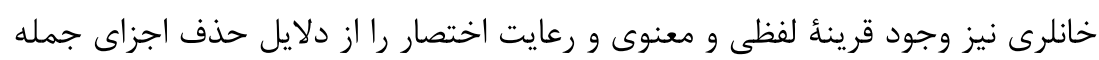

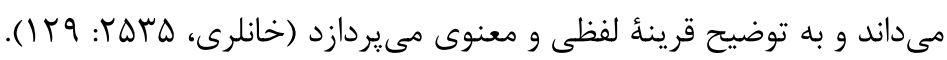


محمدجواد شريعت در دستور زبان خود دربارهٔ حذف مىنويسد: اگتاهى يكى از اركان اصلى يا اجزاى آن كه باعث تبديل جمله كوتاه به جمله بلند مىشوند حذف ميى مردده"

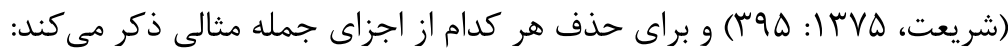

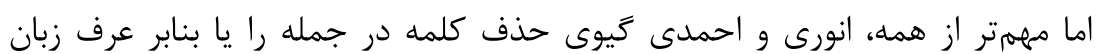
مى دانند، يا به قرينهُ لفظى يا معنوى و در توضيح اين دلايل مى مىنويسند: احذف بنابر عرف زبان يعنى سنت و رسم اهل زبان بر اين است كه براى رعايت اختصار يا به حكم ساختمان خاص جمله و يا به هر دليل ديگرى جمله را با حذف فعل و يا يك يا

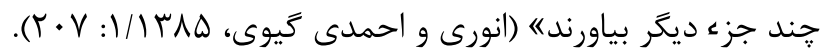

$$
\text { موارد زير از كلستان از همين قبيل است: }
$$

I. جملههايى كه در قسم و دعا و نفرين و امثال آنها به كار مىروند، مانند: ادر اين اميد به سر شد، دريغ، عمر عزيزه (سعدى،

$$
\text { اظهار حسرت و تأسف آمده به معنى لامن دريغ از عمر رفته مى خورمه است. }
$$

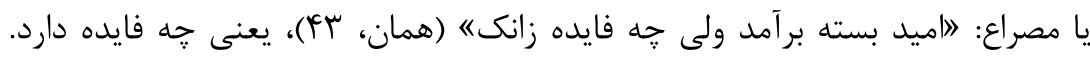
فعل 》دارد" بنابر عرف زبان حذف شده است.

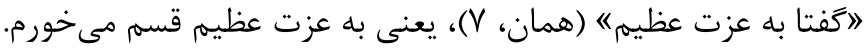

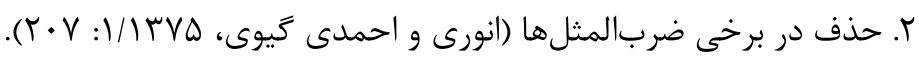

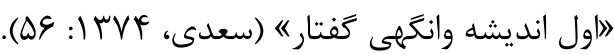

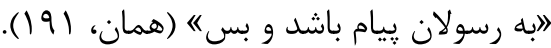

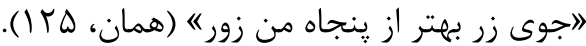

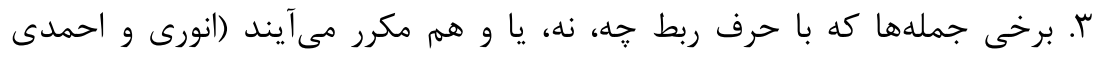

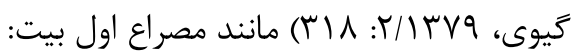

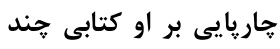
نه محقق بود نه دانشمند (IV) (سعدى، (IVYF)

فعل "بوده در جمله دوم به قرينهُ لفظى و به سبب تكرار حرف انه حذف شده است.

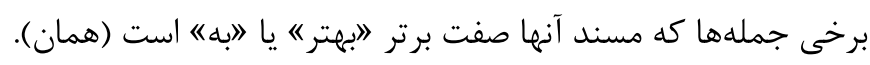
بيشترين مورد حذف در كلستان كه بنابر عرف زبان اتفاق افتاده از اين قبيل است. مانند:

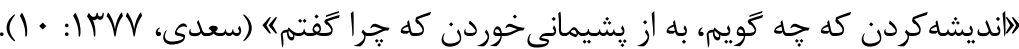
"دروغى مصلحتانخيز به كه راستى فتنهانخيز " (همان، VV). 


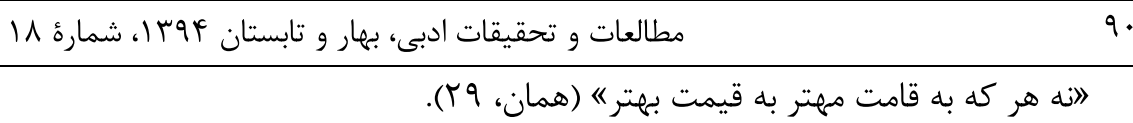

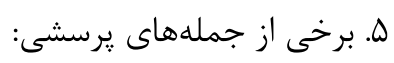

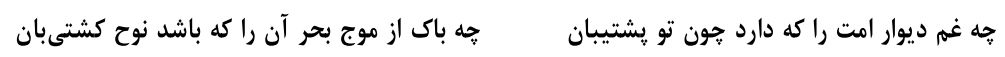

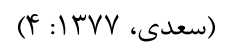

حذف فعل به قرينه لفظى و معنوى

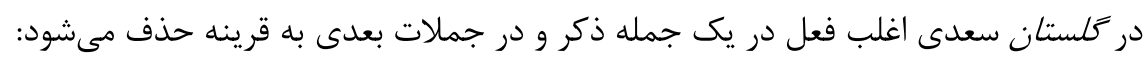

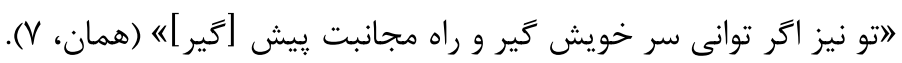

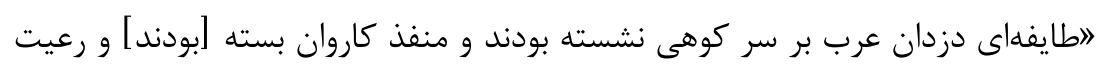

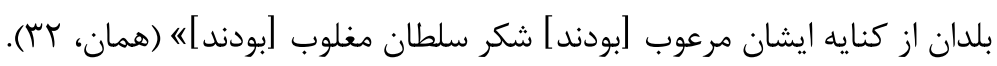

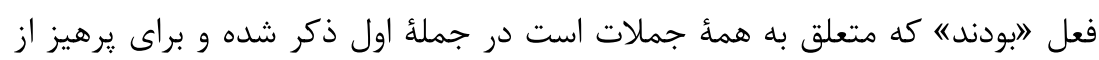

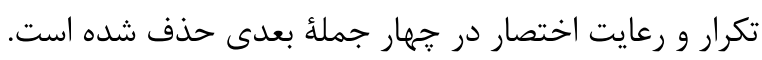

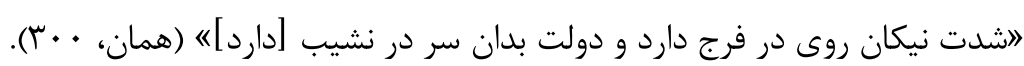

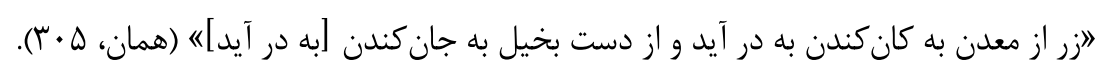

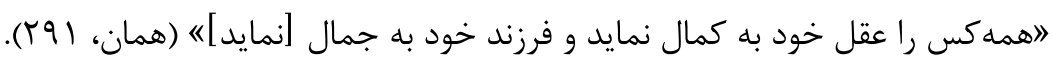

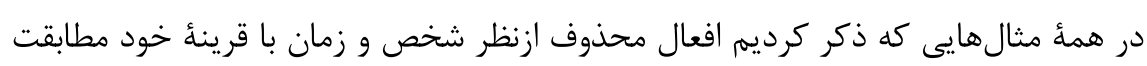

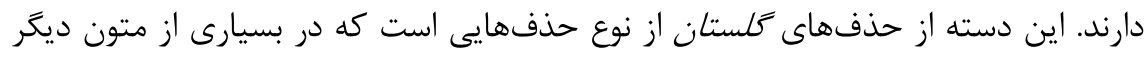

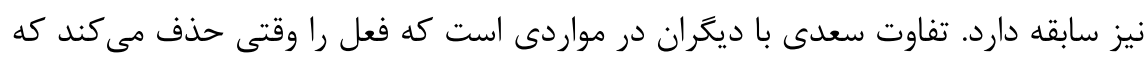

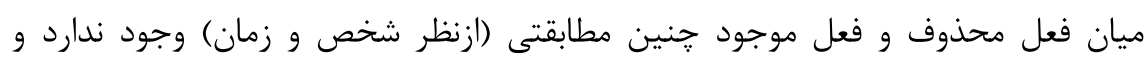

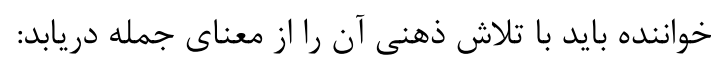

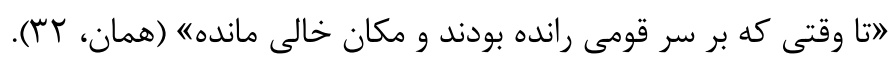

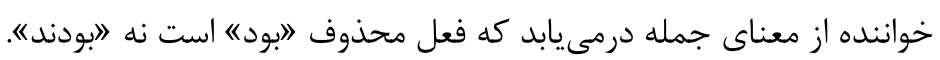

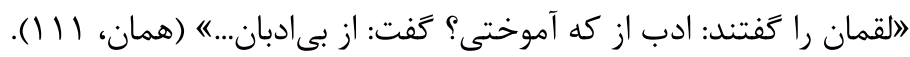

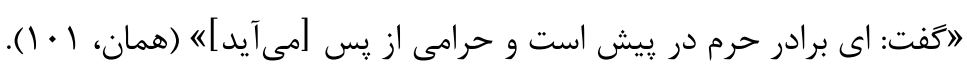

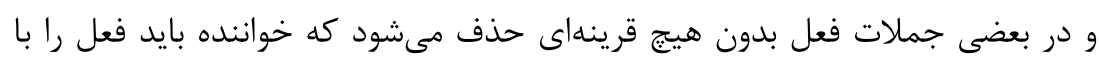
توجه به معنى و سياق جمله دريابد:

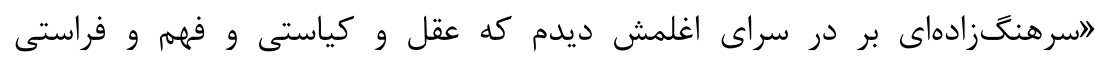

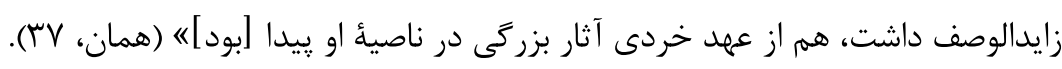

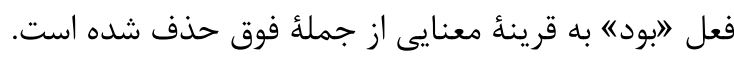




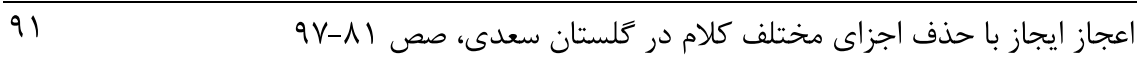

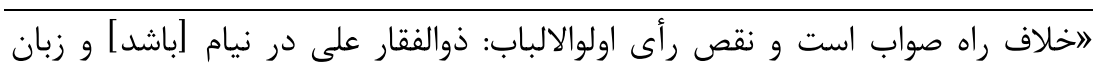
سعدى در كام [باشد] (همان، V). در هر دو جمله فعل "اباشده به قرينهُ معنوى حذف شده است.

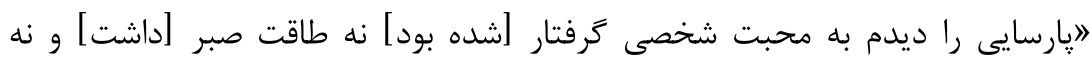
ياراى كفتار [داشت]

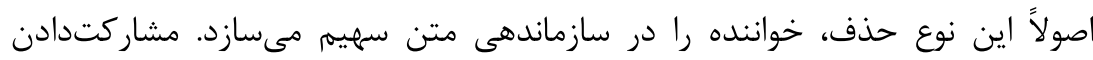

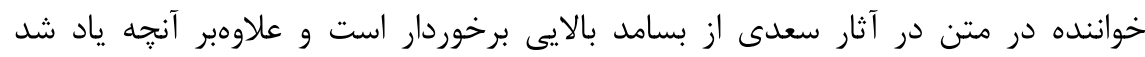

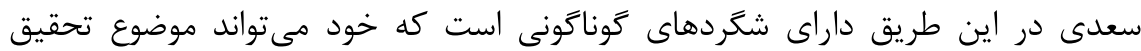
ديكرى قرار بكيرد.

حذف نهاد

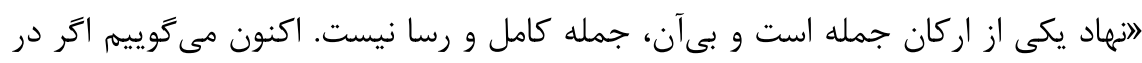

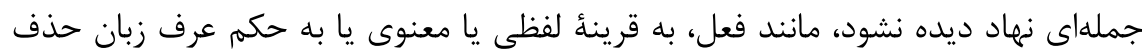
شده است. در اين موارد نهاد حذف مىشود:

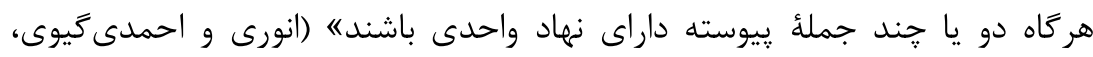
9TV

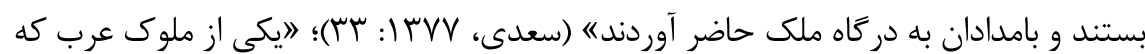

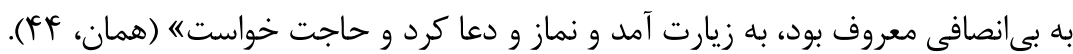

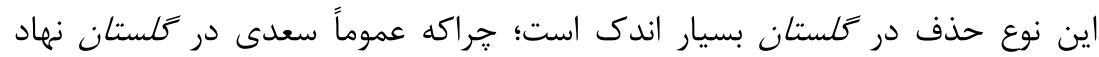

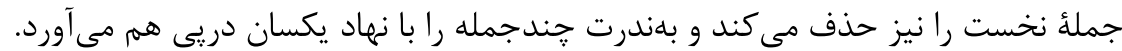

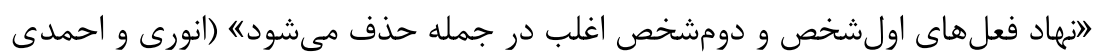

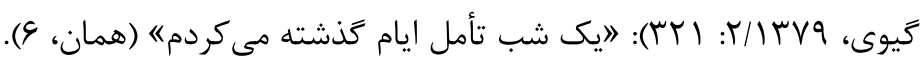

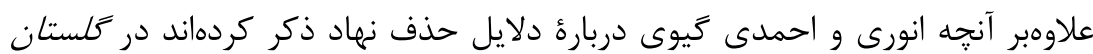
مى توان به اين موارد نيز اشاره كرد: - نهاد از شدت آشكاربودن حذف مى آشود:

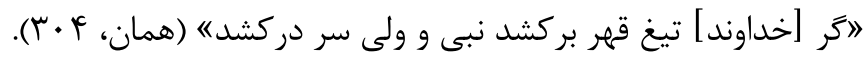
- نههاد به دليل بى اهميتبودن حذف مى شود: 


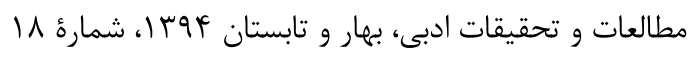
$9 r$

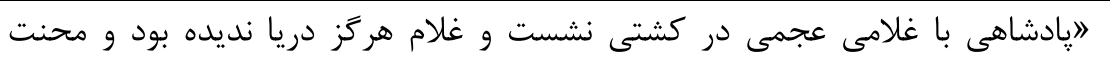

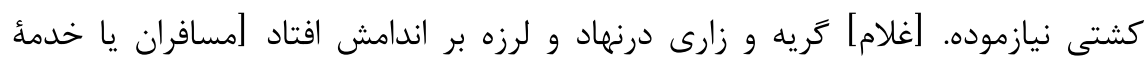

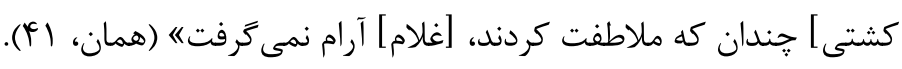

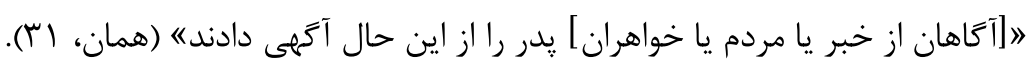

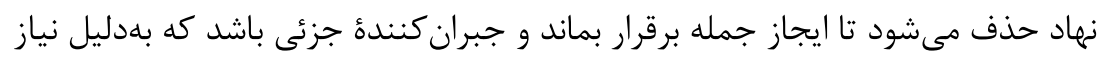

$$
\text { معنايى بر اركان جمله افزوده شده است: }
$$

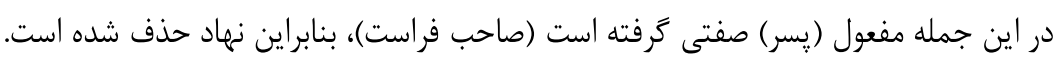

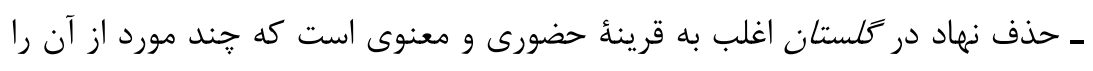
ذكر مى كنيه:

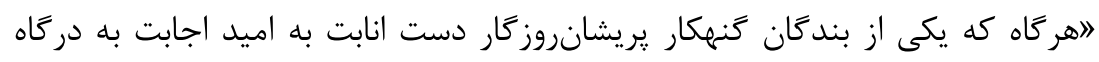

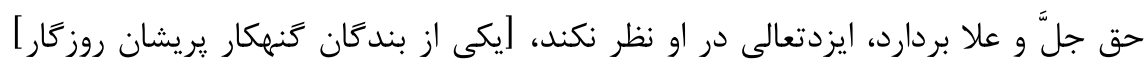

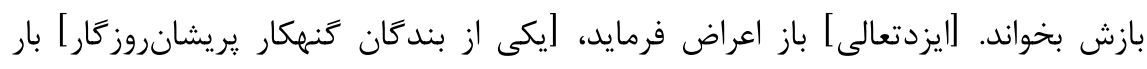
ديخرش به تضرع و زارى بخوانده (همان، أ).

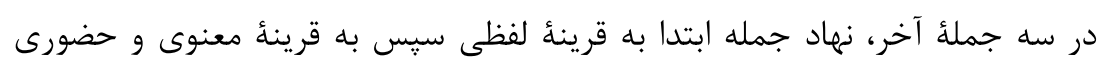

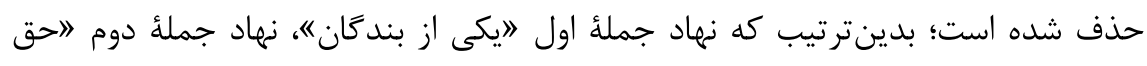

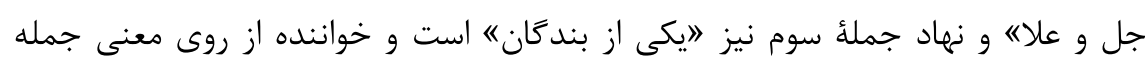

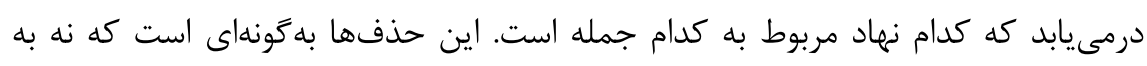

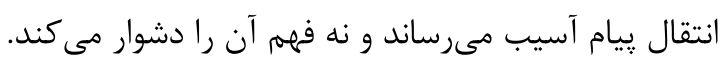

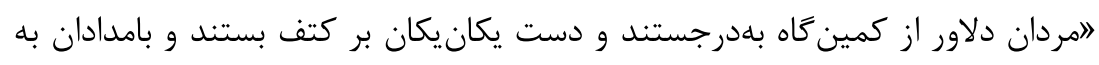

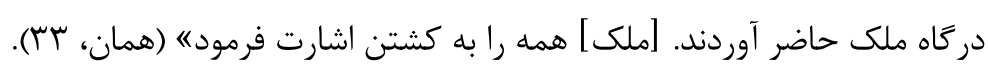

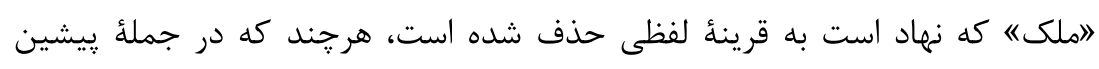

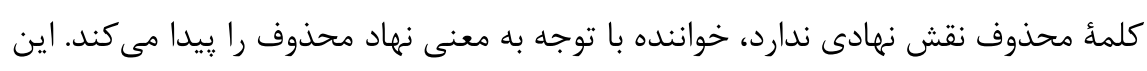

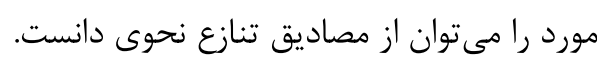

حذف مفعول

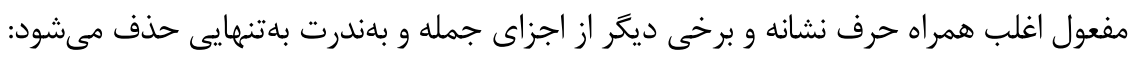

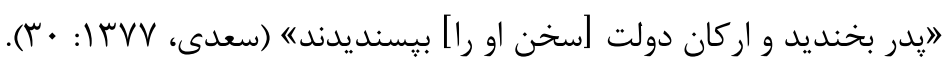
يعنى سخن او را بيسنديدند. "و هر روز نظر بيش كرد و [او را] ولىعهد خويش كرده (همان). 
94

اعجاز ايجاز با حذف اجزاى مختلف كلام در Fلستان سعدى، صص 9V-11

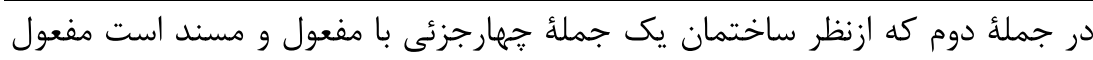
(او) حذف شده است.

"وزير اين سخن بشنيد؛ و [سخن او را] طوعاً و كرهاً بيسنديده (همان، سب).

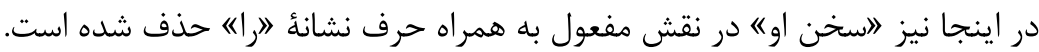

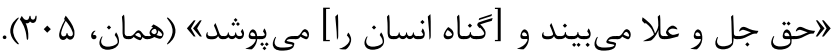
يعنى ״گناه انسان را" مى وبيند.

حذف متمم

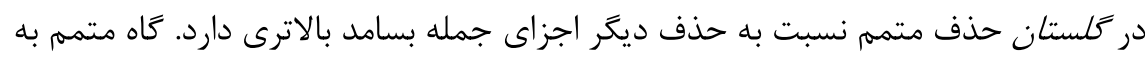
همراه حرف اضافه و برخى اجزاى ديكر جمله حذف مىشود:

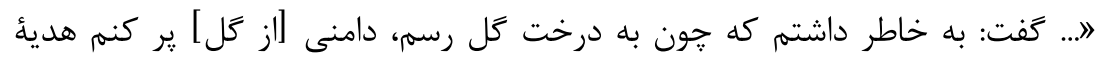

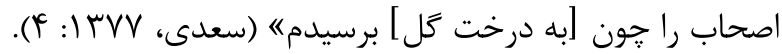

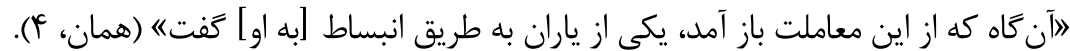

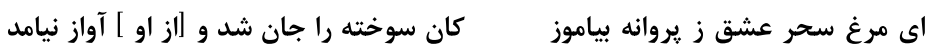

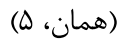

متمم و حرف اضافه بلسبب ضرورت شعرى و قرينهُ معنوى حذف شده است.

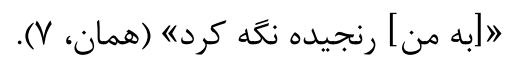

"امن" كه متمم جمله است به همراه حرف اضافه خود به قرينهٔ معنوى حذف شده است. براى نشاندادن كثرت اين نوع حذف، فقط جملاتى را كه متمم در آن حذف شده ذركر

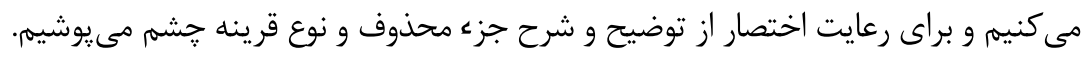
״كه يار موافق بود و ارادت [به او] صادق" (همان، ^).

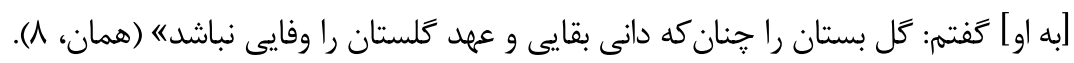

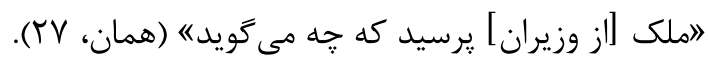

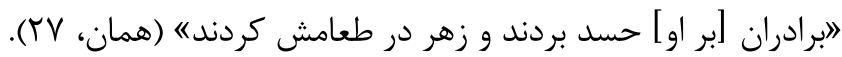

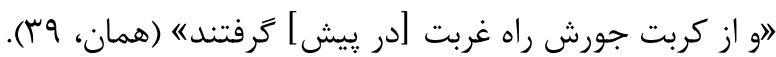

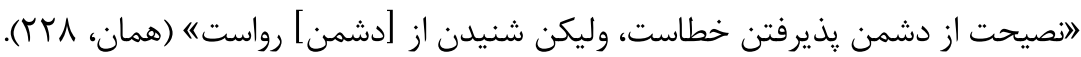

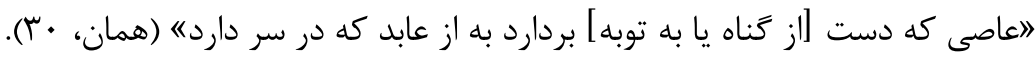


حذف حرف اضافه

يبشتر كفتيم كه در نثر كلستان كاه حرف اضافه همراه متمم خود به قرينه حذف مىشود؛ اما در مواردى فقط حرف اضافه يِيشاز متممم حذف مىشود. حذف حروف اضافه و

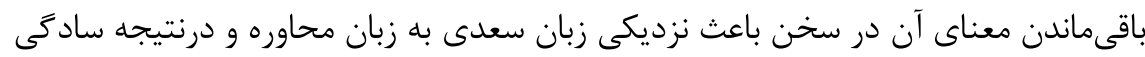

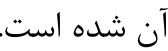

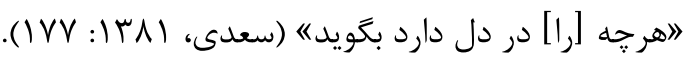

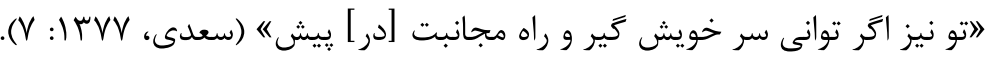

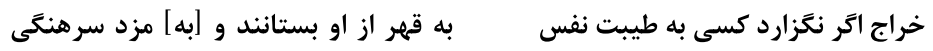

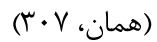

\section{حذف حرف ربط}

در كلستان حذف حرف ربط، علاوهبر ايجاز، سبب روانى و سرعت انتقال كلام نيز مىشود؛

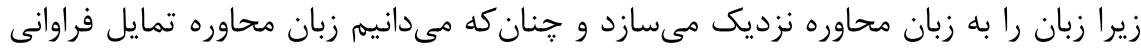
به حذف حروف دارد.

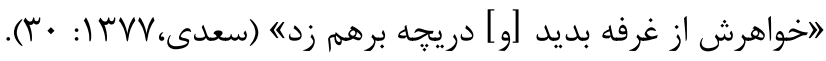

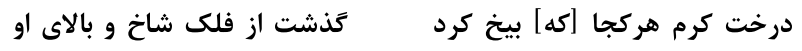

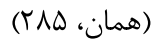

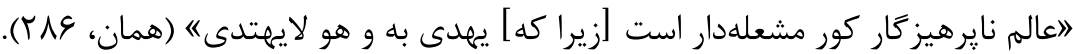

حذف اجزاى ديگر جمله

اجزاى ديكر جمله ازقبيل موصوف، مضاف، صفت، مضافاليه و... نيز كاه حذف مى دوندائ. خلاقيت سعدى در حذف اين عناصر هنغامى يديدار مىشود كه دست به حذف مدف مواردى

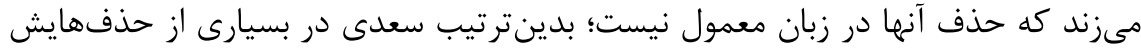

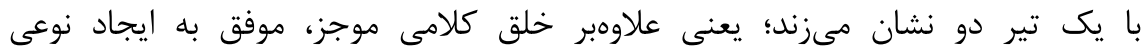
آشنايىزدايى در زبان نيز مىشود:

حذف موصوف به يك ناتراشيده در مجلسى برنجد دل هوشمندان بسى

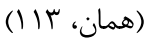

سعدى لفظ "سخن" را كه موصوف "اناتراشيده است حذف كرده است. در اينجا آنجه كلام او را تشخص بخشيده صرف حذف نيست؛ بلكه غرابتى كه از حذف موصوف (سخن) نصيب صفت (نا تراشيده) شده، سبب برجستى كلام وى شده است. 
در اين عبارت حذف موصوف (آدم) در صفتهاى ابلند و كوتها علاومبر آشنايحزدايى در كاربرد اين دو صفت بهجاى موصوف خود، سبب برجستى صنى صنعت تضاد بين دو صفت شده است است.

حذف مضاف

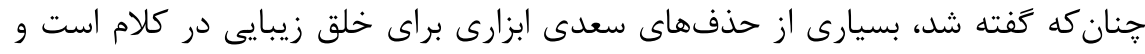

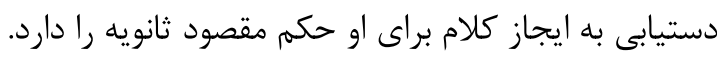

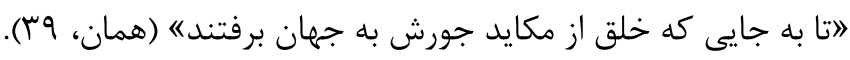

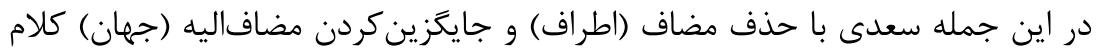

$$
\text { خود را برجسته كرده است. }
$$

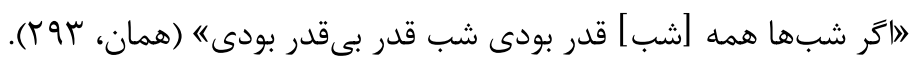

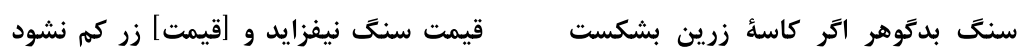

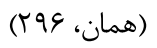

در مثال مزبور حذف كلمدٔ قيمت در مصراع دوم نوعى ايهام بهوجود آورده و سبب زيبايى سخن شده است.

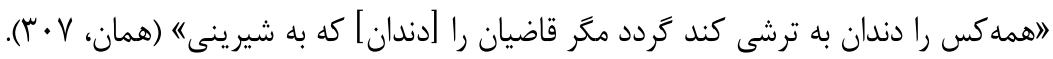

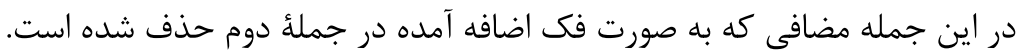

حذف مضافاليه

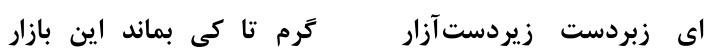

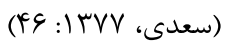

منظور بازار ستمگرى است كه وازٔه ستمگرى به قرينه معنوى حذف شده است و خواننده از مفهوم مصراع اول آن را درمىيابد.

بهجز نمونههاى يادشده، حذفهاى ديكرى نيز در كلستان وجود دارد كه غير از ايجاز

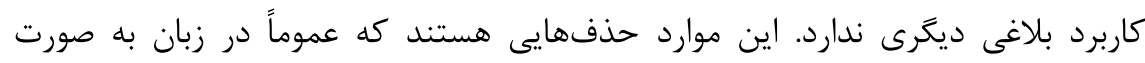
خودكار انجام مىشوند. مثال هاى ذيل از اين نوعاند:

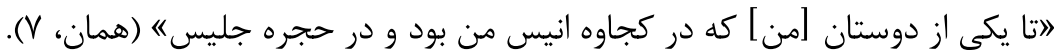




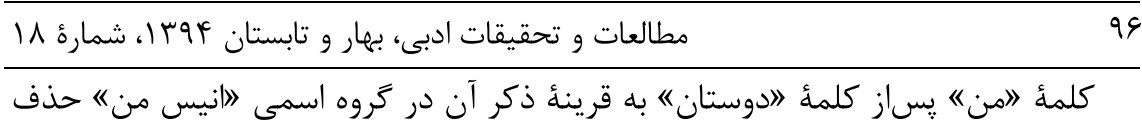
شده است.

"ابر هريك از ساير بندكان و حواشى [ملك] خدمتى متعين استه (همان، • (1).

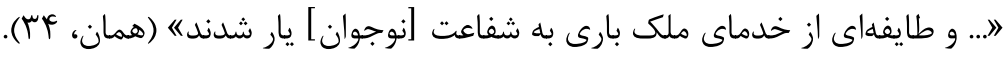

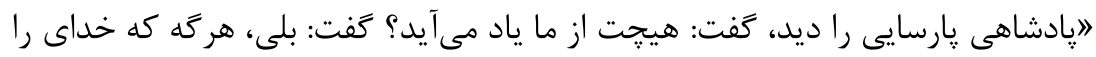

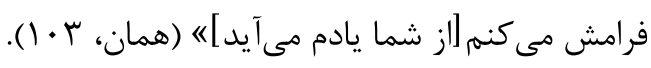

حذف ادات استفهام

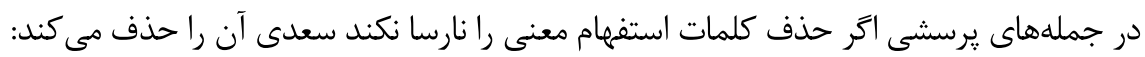

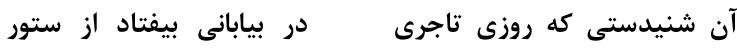

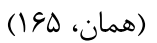
از مفهوم و معنى بيت مى توان فهميد 》آياه در ابتداى بيت حذف شده است. يا: ״َّفت: [آيا] ندانى كه اهل نعمت هميشه محروم باشد؟《 (همان، ؟•r). نتيجه گيرى

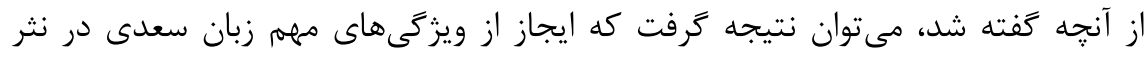

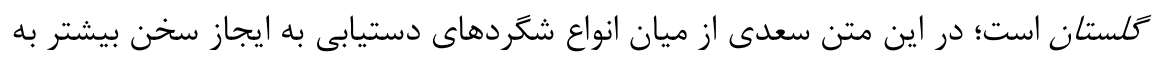

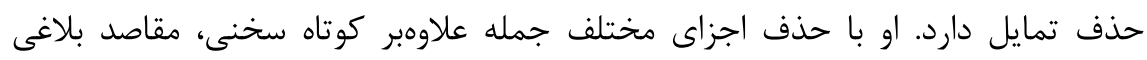

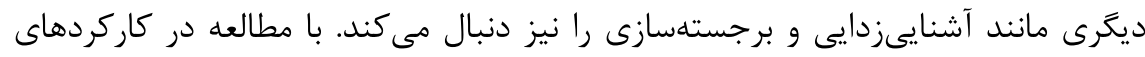

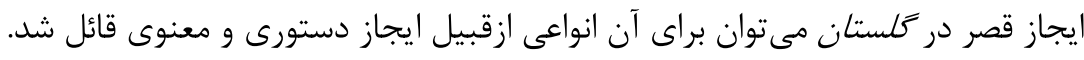

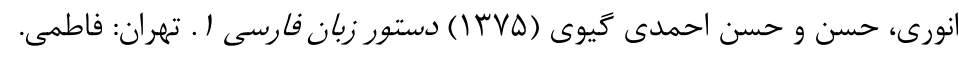

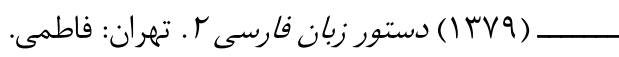

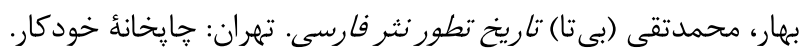

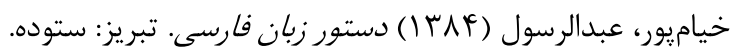

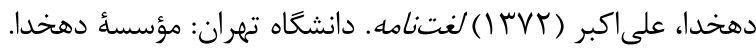

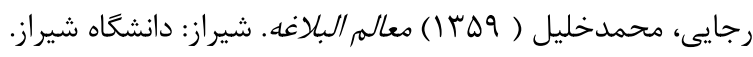

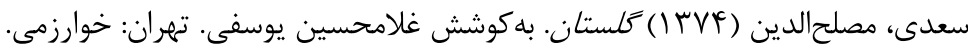


اعجاز ايجاز با حذف اجزاى مختلف كلام در كلستان سعدى، صص 9V-11

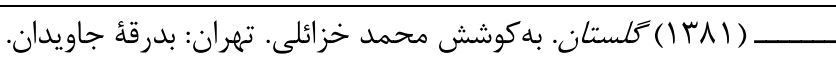

( FVV)

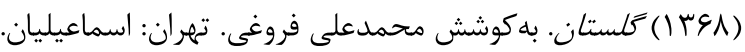

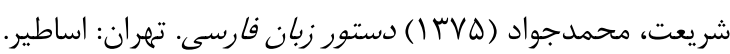

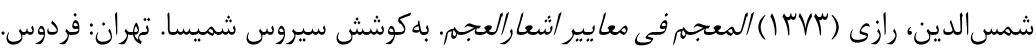

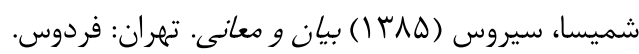

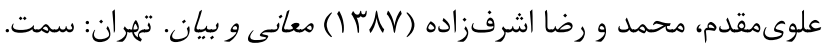

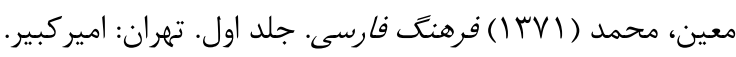

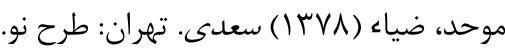

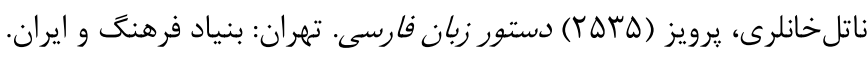

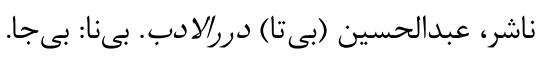

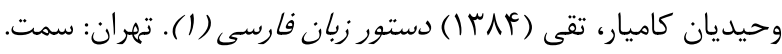

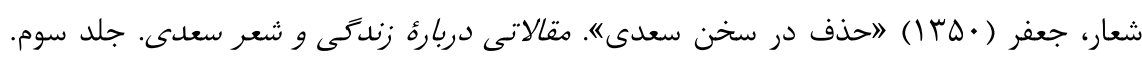

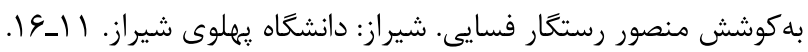

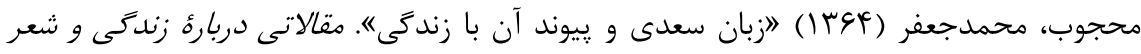

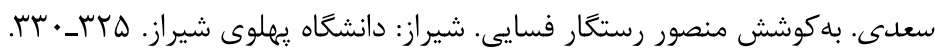

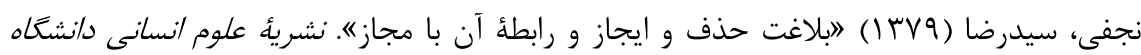

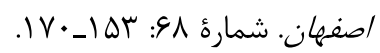

وحيديان كاميار، تقى (ITVY) "ابررسى ترتيب كتاب و و تهذيب ابواب كلستان سعدى". مجلئ

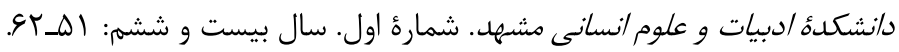

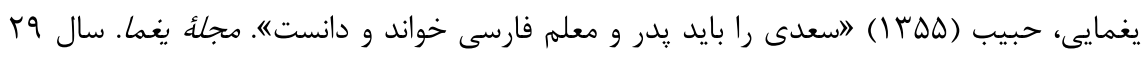

